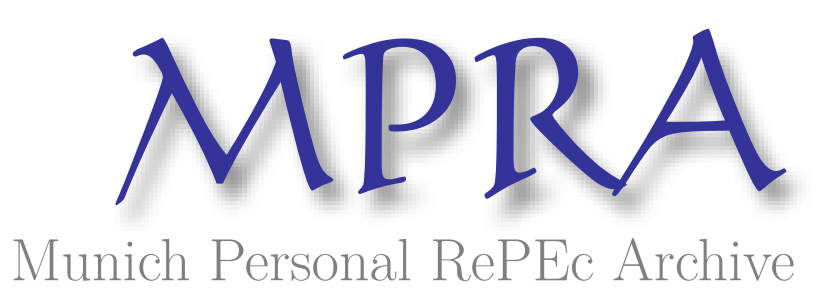

\title{
FDI Spatial Spillovers in China
}

Lin, Mi and Kwan, Yum K.

24 November 2014

Online at https://mpra.ub.uni-muenchen.de/60754/

MPRA Paper No. 60754, posted 25 Oct 2015 02:40 UTC 


\title{
FDI Spatial Spillovers in China
}

\author{
Mi Lin \\ University of Lincoln
}

Yum K. Kwan

City University of Hong Kong

This version: 23 November 2014

\begin{abstract}
This paper studies FDI spatial spillovers in China. Empirical investigation reveals that, along the spatial dimension, FDI presence tends to generate negative intra-regional spillovers that dominate other potential positive externalities. The direction, magnitude and scope of inter-regional spillovers vary, depending on the spillover channels. Our empirical findings call for a rethinking of policy-driven agglomeration among indigenous firms and MNEs in developing countries.
\end{abstract}

Key Words: FDI spillovers; Spatial diffusion; Firm Agglomeration; China

JEL Classification: R12, F21, O33

\footnotetext{
* We would like to thank Professor Cheng Hsiao for technical advice on spatial dynamic panel econometric method. Helpful comments for earlier versions of the paper have been received from Chia-Hui Lu, Larry Qiu, Eden S.H. Yu and seminar participants at City University of Hong Kong, Tsinghua University, University of Waterloo, and Wilfrid Laurier University. All remaining errors are our own. This work is supported by the Research Center of International Economics of City University of Hong Kong (Project No. 7010009).

Correspondences:

Mi Lin, Lincoln Business School, University of Lincoln, UK. Email: linmixm@gmail.com.

Yum K. Kwan, Department of Economics and Finance, City University of Hong Kong. Email: efykkwan@cityu.edu.hk.
} 


\section{INTRODUCTION}

Multinational enterprises (MNEs) have been a major influence on the world economy and the focus of considerable attention. Such enterprises have been at the center of wide-ranging debates both within home countries and in recipient nations. In recipient nations, for example, apart from macroeconomic issues such as tax revenues, employment, exports and economic growth, it is argued that foreign direct investment (FDI) may potentially influence indigenous firms through various spillover effects (Blomström and Kokko, 1998). Over the past two decades, both academic researchers and policy-makers have paid a great deal of attention to FDI spillovers that occur particularly in developing countries. Based on the fact that MNEs on average possess superior technologies or knowledge capital, policy-makers in developing countries seem to take it for granted that there will be beneficial spillovers from MNEs to nearby indigenous firms. Relatively little attention has been paid to the issue of potential negative spillovers. In this study, by exploiting very detailed location information of manufacturing firms in China, we provide empirical evidence showing that negative FDI spillovers can be substantial along the spatial dimension.

Many studies investigate FDI spillovers in the context of firm or industry agglomeration. This is motivated by the Marshallian notion that firms tend to agglomerate in specific areas so as to reduce transaction cost and enjoy external economies. It is well documented in the existing literature that the location of MNEs exhibits similar self-reinforcing pattern not just along the geographical but also the temporal and sectoral dimensions (see, among others, Head et al., 1995; Cheng and Kwan, 2000a, 2000b; Blonigen et al., 2005; Lin and Kwan, 2011). While this line of literature tends to gravitate on the notion that agglomeration promotes spillovers, the direction and magnitude of the association between geographical distance and spillovers, however, is not as clear as one would expect.

The knowledge diffusion literature has long documented the co-existence of both positive and negative spillovers in the context of firm agglomeration. Audretsch and Feldman (1996) and Gertler (2003) emphasize that knowledge diffusion is highly sensitive to geographical distance and that proximity promotes knowledge spillovers. Boschma and Frenken (2010), Broekel and Boschma (2012), and Cassi and Plunket (2013) provide empirical evidence for the prevalence of the so-called proximity paradox, which states that while proximity in various dimensions (geographical, cognitive, organizational, and social) may be a driver for agents to connect and exchange knowledge, too much proximity in any of the dimensions could result in substantially weakened or 
even negative innovative performance and spillovers. It has also been argued that congestion pricing may come along with agglomeration, as excess demand would boost local cost for land, labor, and even public goods, thereby generating negative pecuniary externalities onto the firms. Consequently, while geographical proximity between MNEs and indigenous firms may facilitate knowledge diffusion and hence increase the likelihood of positive spillovers, it can also bring along negative spillovers that adversely affect the performance of indigenous firms (Görg and Greenaway, 2004; Görg and Strobl, 2005).

Many empirical analyses in the literature treat each region as an isolated entity. The role of spatial dependence is completely ignored, even though it has been found to be an important force in the process of productivity growth (Rey and Montouri, 1999; Madriaga and Poncet, 2007). In the context of FDI spillovers, there is no reason why MNCs located in a particular region can only generate spillovers onto indigenous firms collocated in the same region. Similarly, intra- and interregional spillovers can also occur among indigenous firms. The pitfalls of ignoring these spatial interactions, if they actually exist in the data, have also been well documented in the econometric literature (Anselin, 2001). These considerations motivate us to employ in this study a spatial dynamic panel model with both time and spatial autoregressive terms, which simultaneously accounts for spatial interactions among indigenous firms as well as that between indigenous firms and MNEs. The model is estimated by spatial dynamic panel GMM method (Kukenova and Monteiro, 2009) that accounts for endogeneity and spatial dependence problems.

One of the unsolved issues in the FDI spillovers literature is the lack of consensus on the genuine mechanism of spillovers. In most early empirical studies, documented association between domestic firms' productivity performance and FDI presence at most reveal a compounded effect summarizing both positive and negative effects from various channels. To uncover the genuine spillovers realization process, this compounded net effect needs to be further decomposed by adding more dimensions into analysis. Recent literature thus increasingly look at FDI spillovers through industry linkages, origin of foreign ownership, and firm heterogeneities (see Aitken and Harrison, 1999; Javorcik, 2004; Lin et al., 2009; Crespo et al., 2009; Abraham et al., 2010; Hale and Long, 2011; Xu and Sheng, 2012, among other contributions). In this study, we attempt to identify different channels of FDI spillovers by using geography scope. More specifically, although it might be difficult to entirely decompose mixed effects from various channels, we would like to propose that spillovers from different channels have different geography scopes and there is a possibility 
that one source of spillover would become dominant in either narrow or wider geography scope.

As documented in the literature, on the one hand, positive knowledge spillovers (skill acquisition) are more likely through labor turnover (Kokko, 1996; Glass and Saggi, 2002). Using worker flows data in Norway, Balsvik (2011) document that labor mobility from MNEs to nonMNEs represents a true knowledge externality. Moreover, a significant part of knowledge spillovers are through MNCs transfer their techniques, quality systems, standardization procedures to their local suppliers by providing trainings to local labors (Blomström and Kokko, 1998). Markusen and Trofimenko (2007) document that the use of foreign experts by MNCs has substantial, although not always immediate, positive effects on the value added per worker of domestic firms. On the other hand, labor turnover could also generate negative spillovers to domestic firms when foreign firms poach local talents from their domestic counterparts. In terms of the geography scope of spillover through employment, however, the negative effect of poaching local talents are more likely to have narrow scope and are confounded locally. Knowledge spillovers through customer and supplier linkage, imitation, or the transfer of quality systems and standardization procedures nevertheless are less likely to be contained within a small area and thus may become dominant and be identified among wider geographic scope. Based on this stream of literature, we use employment of foreign firms as a proxy to capture FDI spillovers in the empirical model. ${ }^{1}$ Our empirical results seem to support this conjecture, the dominant inter-regional spillover effect captured by employment share of FDI increase from negative to positive when we gradually increase the geographic scope.

Another potential channel for FDI spillovers is through sales competition. Similar to employment, sales competition could potentially capture both positive spillovers, i.e., domestic firms are spurred to become more efficient or to upgrade their technology due to competition (Blomström and Kokko, 1998) or negative spillovers such as market stealing or congestion pricing (Aiken and Harrison, 1999; Görg and Greenaway, 2004; Görg and Strobl, 2005). Our empirical results reveal that negative spillovers in this case are the dominant effect in both limited and wider geographic scopes in our study. Moreover, the negative inter-regional spillovers captured by sales income share of FDI become even negative when geographic scope increases. This could be due to the fact that negative impact of market stealing or congestion pricing are magnified through inter-

\footnotetext{
${ }^{1}$ As we do not have worker flows data, we assume that there is a positive correlation between FDI employment and the likelihood of knowledge spillovers and thus use FDI employment share as a proxy for this channel.
} 
regional trade or industry linkages and spread out in a wider geographic scope; consequently, the positive spillovers captured by sales income share, if exist, seem to be dominated.

The regional distribution of FDI in China was initially determined by government policy but subsequently dominated by agglomeration effect. Five coastal cities were set up as Special Economic Zones (SEZs) in the early 1980s to attract foreign capital by exempting MNEs from taxes and regulations. In view of the success of this experiment, similar schemes, such as Open Coastal Cities (OCCs), Open Coastal Areas, Economic and Technological Development Zones (ETDZs) and Hi-Tech Parks, were also set up to cover broader and inner regions in later years. ${ }^{2}$ During the same period, due to both market- and policy-driven reasons, firm agglomeration has gradually become a distinguished phenomenon of China's economy over the last 20 years.

Explanatory data analyses reveal strong agglomeration pattern for both MNEs location choice and indigenous firms' productivity performance in China. Figure 1 presents FDI spatial density distribution at county level in 2007 (the last year of our sample). FDI presence is measured by fixed asset share of FDI firms in each county. It can be seen from the graph that, while most clusters remain in coastal regions, there are also clusters appearing in central and northern regions of China in recent years. Figure 2 illustrates productivity agglomeration among domestic private firms in China. As shown in the graph, highly productive domestic private firms are mainly clustering in central and inner regions. ${ }^{3}$ A satisfactory empirical model ought to incorporate and explain the agglomeration of productive domestic private firms, as well as the interactions between FDI penetration and indigenous firms in their underlying and neighboring regions. This justifies the use of spatial dynamic panel regression model as the econometric platform in this study.

An interesting phenomenon could be observed when we put Figure 1 and Figure 2 together, i.e., counties with low productive domestic private firms on average have high FDI penetration. Consistent with this observation from explanatory data analyses, our empirical results show that

\footnotetext{
${ }^{2}$ From 1984 to 1986, 14 Open Coastal Cities were set up in Fujian, Guangdong, Guangxi, Hebei, Jiangsu, Liaoning, Shandong, Shanghai, Tianjin, and Zhejiang provinces. To date, there are 54 national-level ETDZs located in Beijing, Shanghai, Zhejiang (Ningbo and Hangzhou), Jilin (Changchun), Fujian (Dongshan, Fuzhou and Xiamen), Jiangxi (Nanchang), Jiangsu (Nanjing, Changzhou, Suzhou and Wuxi), Anhui (Wuhu), and Guangdong (Foshan, Guangzhou, Zhongshan, Huizhou, Shenzhen and Zhuhai) etc. More detailed information can be obtained from: http://www.china.org.cn/english/features/etdz/75721.htm.

${ }^{3}$ In this paper, we define domestic private firms as firms that do not have positive equity invested by the state or foreign investor. This excludes FDI, Sino-Foreign Joint Ventures, and SOEs from the sample when we plot Figure 2. This is the main reason why the results presented in the graph are different from the common impression of TFP distribution in China. Coastal regions do on average have higher productivity but this is mainly due to the fact that many high productive FDI and Sino-Foreign Joint Ventures are located in coastal regions.
} 
FDI presence in a locality will generate negative and significant impact on the productivity performance of domestic private firms in the same location. This result is robust to different spillover measures.

Many studies have addressed FDI spillovers in China. Using aggregate industrial data, Liu (2002) documents that FDI generates positive spillover impact on the productivity of manufacturing industries. Cheung and Lin (2003) find that FDI presence has positive impacts on the number of patent applications filed by indigenous firms in China. Lin et al. (2009) use both industry linkage and ownership structure to decompose FDI spillover from various sources. They find that spillovers from Hong Kong, Macao, and Taiwan (HMT) firms are mainly negative while spillovers generated by non-HMT firms tend to be positive. At the aggregate level, these two opposing effects tend to offset each other. The same paper also documents strong and robust vertical spillovers. There are also a few studies look at FDI spillovers through geographical dimension. Using a cross-sectional firm level dataset from four provinces in Yangtze River Delta area in China, Tanaka and Hashiguchi (2012) document that FDI agglomeration generates stronger positive spillovers to domestic firms in nearby areas than in distance areas. Ouyang and Fu (2012) document that FDI concentrated in China's coastal cities contributes to the growth of inland cities.

The rest of this paper is organized as follows. Sections 2 and 3 discuss the empirical model, the data set and econometric issues. The empirical results can be found in Section 4. The final section concludes and suggests policy implications.

\section{[Insert FIGURE 1 and FIGURE 2 here]}

\section{EMPIRICAL MODEL}

We employ the spatial dynamic panel regression model in equation (1) as the platform for our empirical analysis, where the spatial weights $w_{i j}$ are inversely proportional to the Euclidean distance $d_{i j}$ between two regions $i$ and $j$ :

$$
\begin{aligned}
T F P_{i t} & =\tau T F P_{i t-1}+\rho \sum_{j=1}^{N} w_{i j} T F P_{j t}+\beta_{1} S O E_{-} \text {presence }_{i t}+\gamma_{1} \sum_{j=1}^{N} w_{i j} \text { SOE }_{-} \text {presence }_{j t} \\
& +\beta_{2} F D I_{-} \text {presence }_{i t}+\gamma_{2} \sum_{j=1}^{N} w_{i j} F D I_{-} \text {presence }_{j t} \\
& +\delta_{t}+\alpha_{i}+\varepsilon_{i t}
\end{aligned}
$$




$$
i=1,2, \cdots, N \text { and } t=1999, \cdots, 2007 \text {. }
$$

where

$$
w_{i j}=\left\{\begin{array}{ccc}
\left(d_{i j}\right)^{-1} & \text { if } & i \neq j \\
0 & \text { if } & i=j
\end{array}\right.
$$

The dependent variable, regional $T F P_{i t}$ in (1), is a weighted average of the firm-level total factor productivity (in logarithm) of domestic private firms in region $i$ at time $t$, with the weights being the value added shares of the corresponding firms located in the underlying region in each year. ${ }^{4}$ The spatial autoregressive term, $\rho \sum_{j=1}^{N} w_{i j} T F P_{j t}$, allows productivity spillovers among domestic firms which accounts for the productivity agglomeration pattern observed in the data. The temporal autoregressive term, $\tau T F P_{i t-1}$, introduces dynamic adjustments into the model which allows the graduate diffusion of spillover effects over time. Domestic productivity in region $i$ will be influenced by both intra- and inter-regional FDI presence, namely, FDI located in the same region FDI_presence it $_{\text {and }}$ a weighted average of FDI located in neighboring regions $\sum_{j=1}^{N} w_{i j} F D I_{-}$presence $_{j t}$. The parameters $\beta_{2}$ and $\gamma_{2}$ measure intra- and inter-regional FDI spillover effect, respectively. Following the literature discussed above, we construct two proxies for FDI presence, namely, employment and sales income share of foreign firms in a region:

$$
\begin{aligned}
F D I_{-} \text {Employment }_{i t} & =\frac{\text { Employment }_{i t}^{F D I}}{\text { Employment }_{i t}^{T}} \\
F D I_{-} \text {Sales Income } &
\end{aligned}
$$

where the superscript ' $T$ ' refers to all firms (both domestic and foreign) in a region, and superscript ' $F D I$ ' refers to foreign firms only. These two proxies are expected to at least partially identify different channels of FDI spillovers, namely, (a) spillovers passing through workers (such as positive knowledge spillovers from labor market turnovers, learning-by-watching, imitation, etc. or negative spillovers from MNEs poaching local talents and bidding up local wages) and (b) spillovers passing through the product market (such as market stealing effect or competition effect). Since we cannot rule out multiple spillover effects, possibly of opposite sign, passing through the

\footnotetext{
${ }^{4}$ Appendix A reports details on variable construction and TFP estimation.
} 
same channel at the same time, the current setup will only be able to capture the dominant or net effect.

In view of the prominence of the state-owned sector in China and its well-documented impact on the private sector, we also include the fixed asset share of state-owned enterprises in a region as an additional explanatory variable:

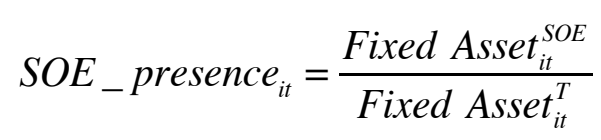

where superscripts ' $T$ ' and ' $S O E$ ' refer to all firms and state-owned firms respectively. ${ }^{5}$ Finally, with the aid of the panel data structure, we include two fixed effects to mitigate the problem of omitted variables. Time-specific fixed effect $\delta_{t}$ captures macroeconomic or policy events that have nationwide impact on productivity; and region-specific fixed effect $\alpha_{i}$ captures unmeasured local characteristics that explain productivity such as industry mix, institution, geography and education.

The spatial weight matrix $W=\left[w_{i j}\right]$ parameterizes the structure of spatial dependence across the $N$ regions. We employ three different spatial weight matrices in our empirical analysis. The first one is a full matrix, which allows every region to be spatially connected to all other regions, i.e., non-zero input in all non-diagonal elements. The other two are truncated versions of the full matrix. We first partition the value of $w_{i j}$ (in ascending order) into 5 bins. We then construct two truncated matrices, namely, $W^{c 1}$, of which only the weights of the closest $1 / 5$ neighboring regions remain positive and the rest are truncated to zero, and $W^{c 2}$, of which only the closest $3 / 5$ neighboring regions receive positive weights. For each FDI proxy (i.e. employment share or sales income share), we fit three separate spatial dynamic panel equations using each of $W^{c 1}, W^{c 2}$, and $W$. By doing so we are effectively using the geographic scope of spillover mechanism as identification condition. Hopefully this will help us further distinguish spillover effects that pass through the same channel (i.e. either employment share or sales income share). Following the literature discussed above, it is reasonable to expect different spillover mechanisms should have different geographic scopes. For example, negative spillovers due to poaching of local talents and

\footnotetext{
${ }^{5}$ We include this variable as an independent variable as, apart from FDI, state owned firms would also have impact on domestic private firms. On the one hand, the investment by SOEs could enhance local capital accumulation and thus contribute to the agglomeration process. On the other hand, as documented in the literature (Bai et al., 2000; Bai et al., 2004; Huang, 1998 and 2008; Huang et al, 2008), SOEs might generate crowding out effect, as well as create distortions in both input and output market (especially in financial market), which all have significant impact on private firms. Without controlling the impact of SOEs, our estimation results might suffer from omitted variable bias.
} 
congestion pricing should have a more limited geographic scope, compared with knowledge spillovers through vertical linkage or imitation which should be less constrained by geographic distance.

\section{DATA AND ESTIMATION ISSUES}

Data employed in this paper come from the annual census of above-size manufacturing firms conducted by the National Bureau of Statistics (NBS) of China from 1998 to 2007 (known as the Chinese Industrial Enterprises Database, NBS-CIE database henceforth). The database covers manufacturing firms with sales revenue over 5 million RMB. There are several indexes (including the China standard location indicator, district code, province code, city code, county code, as well as firms' full address) which can help us to identify the location of a firm. Among all these indexes, province code, city code and county code are most completed and consistent over years. Measures specifying the distance between individual firms are not available. We hence define 'region' at county level in the empirical analysis. Consequently, all variables in this paper are aggregate county level data from an unbalanced panel data set with the number of regions ranging from 1343 in 1998 to 2210 in 2007 . The longitude and latitude coordinates of the counties are obtained from the GIVA-GIS database which are merged into the CIE database for producing the spatial weights.

Domestic private firm in this paper is defined as firms that do not receive paid-up capital from foreign investors or from any level of the Chinese government. ${ }^{6}$ Foreign firms are firms with positive foreign equity share in the sample. ${ }^{7}$ The dependent variable, total factor productivity at county level, is obtained by firstly estimating the total factor productivity at firm level and then aggregate them up to the county level. More specifically, we first estimate firm level TFP industry by industry using Levinsohn and Petrin (2003) method, which corrects for endogeneity bias in

\footnotetext{
${ }^{6}$ This study does not attempt to address and evaluate the impact of FDI on the productivity of China's state-owned enterprises. Bearing missions like stabilizing price and mitigating unemployment, it is not appropriate to model China's state-owned enterprises have the same objective function as private firms. This issue may be investigated in future research. NBS-CIE database also reports registered ownership type which can also be used to identify firms' ownership structure. In our paper, we identify FDI by using owner's equity structure (paid-in capital) as we observe that in the databased there are firms with unchanged ownership type when their owner's equity structure actually has changed. Defining FDI using owner's equity structure thus is a better approach to reflect FDI penetration at firm level.

${ }^{7}$ Summary statistics show that, among firms with positive foreign equity, most of them have foreign equity larger than $10 \%$. For instance, in 1998, 97\% firms of this group have foreign equity larger than $10 \%$ (OECD definition of FDI) and $87 \%$ have foreign equity larger than $25 \%$ (FDI definied by Chinese law). In 2007 , the numbers are $98 \%$ and $93 \%$ respectively. As firms with foreign share less than $10 \%$ (25\%) only on average account for less than $5 \%(10 \%)$ of our sample, we believe that this difference will not lead to a significant change in our empirical results.
} 
production function estimation arising from potential correlation between input levels and unobserved firm-specific productivity shocks. County level TFP is then constructed by calculating the weighted average firm level TFP in logritham, with the weights being the value added shares of the corresponding firms located in the underlying county in each year. In Appendix I, we provide further details on the description of data and variables, as well as the estimation procedure of TFP.

Kukenova and Monteiro (2009) advocate the use of the system-GMM estimator (Arellano and Bover, 1995; Blundell and Bond, 1998) to estimate the spatial dynamic panel model. In their Monte-Carlo experiments the system-GMM estimator outperforms various other spatial dynamic panel estimators in terms of bias, root mean squared error and standard error accuracy. Jacobs et al. (2009) confirm the conclusion of Kukenova and Monteiro (2009) in an independent Monte-Carlo study of the system-GMM estimator applied to the spatial dynamic panel model. They also document that the combination of collapsing the instrument matrix and limiting the lag depth of the dynamic instruments substantially reduces the finite sample bias in estimating the spatial lag parameter. In view of these recent developments in the econometric literature, we adopt the spatial system-GMM estimator as our estimation method in this study.

\section{EMPIRICAL RESULTS}

Table 1 and 2 report empirical results based on two different proxies for FDI presence, i.e., sales income share and employment share, respectively. We also use different TFP measures as dependent variable to perform robustness check. ${ }^{8}$ As shown in both tables, both estimated temporal and spatial autoregressive coefficients are positive and significant under different model specifications, suggesting fairly strong temporal and spatial self-perpetuating pattern of productivity for domestic private firms at county level. These results are consistent with the explanatory data analyses reported in Figure 2. Positive spatial autoregressive coefficient indicates agglomeration pattern of indigenous firms' TFP while positive temporal autoregressive coefficient reveals fairly persistent self-reinforcing trend of TFP over time.

\footnotetext{
${ }^{8}$ The difference between TFP measures 1 and 2 are mainly due to using different capital series and deflators in the firm-level TFP estimation. For TFP measure 1 we use the sum of average circulating capital and net value of fixed assets as proxy for capital input, which is deflated by investment deflators obtained from various issues of Chinese Statistics Yearbook. For TFP measure 2, both capital input and deflator follow Brandt, Van Biesebroeck, and Zhang (2012 and 2014).
} 
In Table 1, both intra- and inter-regional FDI spillovers are negative and significant across different model specifications. This suggests that negative pecuniary externalities from market stealing effect and congestion pricing seem to be dominant in both intra- and inter-regional dimensions when FDI presence is measured by sales income share. Note that when we gradually increase the number of neighbors by using different truncated spatial weight matrices, inter-regional spillovers captured by the estimated coefficient of spatially lagged FDI presence under TFP measure 1 decreases from -6.362 to -7.133 , and further down to -13.093 when the spatial weight matrix is not truncated. The same pattern can be observed when TFP measure 2 is used in the regression. This result indicates that the intensity of pecuniary externalities increases when the range of neighboring regions expands. These negative pecuniary externalities seem to have wide geographic scope and outweigh other potential positive spillovers in both intra- and inter-regional dimensions. This could be due to the fact that the negative impact of market stealing or congestion pricing are magnified through inter-regional trade or industry linkages and spread onto a wider geographic scope; consequently, the positive spillovers captured by sales income share, if exist, seem to be dominated.

In Table 2, FDI presence is measured by employment share to capture potential positive knowledge spillovers from labour market turnovers as well as negative externality from MNEs poaching local talents. Empirical results show that intra-regional spillovers are negative and significant across different model specification, suggesting fairly strong negative effect of MNEs poaching local talents from indigenous firms in the same locality. The magnitude of inter-regional spillovers measured by the estimated coefficient of spatial lag FDI presence under TFP measure 1 increase from -4.695 to -3.027 , and further increase to 1.437 when the spatial weights matrix incorporates all neighbors. Very similar pattern is observed when we use alternative measure of TFP. This result reveals that, when FDI spillovers are measured by employment share, captured negative pecuniary externality and positive knowledge spillovers may have different geographic scopes. Negative pecuniary externalities tend to become dominant when only very close neighbors are incorporated in the analysis and thus have very local and narrow scope. Positive knowledge spillovers, however, become dominant when we expand the range of neighboring regions to incorporating more neighbors and thus have wider scope.

The presence of SOEs seems to generate significant and negative impacts on domestic firms in the same locality. This is consistent with the results documented in the literature. The presence of 
SOEs tend to generate crowding out effect as well as distortions in both input and output market, which all have negative impact on domestic firms. The inter-regional impact of SOEs presence, however, are mostly positive and significant. The potential reason of this positive inter-regional effect might be that investment of SOEs in the neighbouring regions accelerate capital accumulation and thus contribute to the benefit of agglomeration process. Moreover, SOEs in China tend to focus on local regional market due to well-documented cellular structure of Chinese market, which could also be the reason that private firms are less affected by SOEs from neighbouring regions.

Our empirical results document fairly strong evidence of substantial negative FDI spillovers along the spatial dimension, which calls for the rethinking of the commonly made presumption of beneficial spillovers from MNEs to nearby indigenous firms. By incorporating spatial dimension in the analysis, we are able to uncover the dominance of FDI negative spillovers and their scopes in space that have not been identified in conventional regression model in the FDI spillovers literature. Negative pecuniary externalities through market stealing effect and congestion pricing effect seem to have considerably wider scope as shown by the empirical results in Table 1 . The second sources of negative pecuniary externalities come from MNEs poaching local talents from indigenous firms in the same locality. Nevertheless, this type of negative spillovers decrease with distance as suggested by the empirical results in Table 2. Potential benefit from FDI through knowledge spillovers are identified when we search for externalities from regions that are distance away. These results suggest that the benefit of indigenous firms locating close to MNEs may not be as large as commonly believed. Negative pecuniary externalities tend to dominate other potential positive externalities resulting in negative overall effect.

\section{CONCLUSION}

Recent literature has reached the consensus that FDI spillovers do not occur uniformly and unconditionally. Empirical studies looking at the simple association between domestic firms' productivity performance and FDI presence may only summarize the compounded effect resulting from various factors but hardly reveal the underlying mechanism. It is thus important to introduce extra dimension in the analysis so as to disentangle the FDI spillovers mechanism. This study incorporates spatial dimension and investigates the geographic extent of FDI spillovers based on a large panel dataset of Chinese manufacturing firms supplemented with GPS information down to county level. We employ spatial dynamic panel econometric techniques to uncover the spatial 
extent of spillover diffusion. Our empirical results show that FDI presence in one county will generate negative spillovers to domestic private firms in the same locality. This result is robust to different proxies for FDI presence. We further document strong negative pecuniary externalities through market stealing effect and congestion pricing effect in inter-regional dimension. By gradually expanding the range of the spatial weights matrix, we also identify potential positive knowledge spillovers which tend to have wide geographic scope.

Many developing countries including China have been providing incentive packages to encourage agglomeration among indigenous firms and MNEs. While the initial intention is to provide 'learning by watching' opportunity for domestic firms as well as promoting collaboration and knowledge sharing amont domestic and foreign firms, geographical concentration may at the same time enhance the occurrence of negative pecuniary externalities. Our empirical investigation reveals that FDI-induced negative pecuniary externalities may be substantially stronger than other potential positive externalities. The benefit of agglomeration among indigenous firms and MNEs may not be as large as commonly believed. Indigenous firms however can potentially benefit from knowledge spillovers from MNEs located distance away. The empirical results of this study thus calls for a re-evaluation of the potential outcomes of policy-driven clustering among indigenous firms and MNEs. 


\section{APPENIDX A: Data, Variable, and TFP Measure}

Data employed in this paper come from the annual census of above-size manufacturing firms conducted by the National Bureau of Statistics (NBS) of China from 1998 to 2007 (known as the Chinese Industrial Enterprises Database, NBS-CIE database henceforth). In a very detailed and thorough approach, Brandt, Van Biesebroeck, and Zhang (2012 and 2014) address variables and data cleaning issues of NBS-CIE database. We closely follow the data cleaning strategy suggested by their studies and make use of their industry concordances as consistent industry identifier. ${ }^{9}$ We drop firms with employment (personal engaged) below 8 workers and with negative nominal capital stocks, paid-up capital, sales revenue, intermediate inputs, or employment. Nominal input and output variables reported in the NBS-CIE databased are deflated by input and output deflators at 2digit industry level $(1998=100)$ provided in Brandt, Van Biesebroeck, and Zhang (2012 and 2014).

The construction of real capital stock merits special attention. Firms in the databased do not report fixed investment. Fixed capital stock data are reported at original purchase prices and thus cannot be used directly in the TFP estimation. We thus construct two proxies for capital input: 1) We use the sum of average circulating capital and net value of fixed assets as proxy for capital input. This capital input proxy is deflated by the investment price index $(1998=100)$ obtained from various issues of China Statistical Yearbook; 2) Following Brandt, Van Biesebroeck, and Zhang (2012 and 2014), we convert estimates of capital stock at original purchase prices into real values that are comparable across time and firms. More specifically, we first make use of the capital stock data reported in 1993 annual enterprise survey and in 1998 NBS-CIE database to estimate average growth rate of the nominal capital stock between 1993 and 1998 at province by industry (2-digit) level. By using this estimated growth rate $(g)$, which is different by industy and by year, together with capital stock at original purchase price $\left(f a^{\text {initial }}\right)$ and the firm's age $(a)$ we calculate the firm's initial nominal capital stock $\left(n k_{0}\right)$ in the establishment year, $n k_{0}=f a^{\text {initial }} /(1+g)^{a} \cdot{ }^{10}$ The firm's real capital stock in the establishment year $\left(r k_{0}\right)$ is obtained by deflating $n k_{0}$ using investment deflator from Perkins and Rawski (2008). Nominal capital stock data after the establishment year is then

\footnotetext{
${ }^{9}$ There was a revision of industry classification of China in 2002. A concordance thus is needed to make industry identifier to be consistent across the sample period.

${ }^{10}$ Following Brandt, Van Biesebroeck, and Zhang (2012 and 2014), we assume that, for firms with establishment year earlier than 1978, their experience before 1978 have negligible impact on capital stock in 1998 and thus reset the establishment year for these firms to 1978 .
} 
calculated by using the estimated growth rate $(g)$. Assuming a 9\% depreciation rate, the real capital stock data in 1998 (or the firm's first year in the sample) is then calculated by using perpetual inventory method and Perkins and Rawski deflators. Real capital stock after 1998 (or after the firm's first year in the sample) is calculated by following perpetual inventory method with $9 \%$ depreciation rate but use the difference in firm's nominal capital stock measured at original purchase prices as fixed investment.

The first step of our data analysis is to estimate the total factor productivity in logarithm, $\ln (T F P)$, at firm level. The county-level TFPs are constructed as the weighted average of firmlevel $\ln (T F P) s$ with the weights being the value added shares of the firm in the underlying county and in each year. Specifically, $T F P_{i t}$, for county $i$, in year $t$ is constructed as

$$
T F P_{i t}=\frac{v a_{j i t}}{\sum_{j \in i} v a_{j i t}} \ln (T F P)_{j i t}
$$

where $v a_{j i t}$ denotes the year $t$ 's value added for firm $j$ located in county $i$.

A conventional way to estimate TFP is to apply ordinary least squares on Cobb-Douglas production function and use Solow residue as a measure of TFP. This approach, nevertheless, has been criticized by recent literature in that it does not handle the potential endogeneity problem arising from potential correlation between input levels and unobserved firm-specific productivity shocks. Firms make input decision after they observe their current productivity level; thus, the input variables are not exogenous variables. Without controlling for firms' productivity, which is typically unavailable in most cases, OLS could result in bias in the production function regression and in TFP measure. To correct for endogeneity bias in production function estimation, Levinsohn and Petrin (2003) propose to use intermediate input as instrument in the estimation. This algorithm has now commonly adopted in the literature to handle the endogeneity bias problem in TFP estimation. We hence also employ this method in this paper. The followings provide a brief summary for Levinsohn and Petrin (LP) routine.

Assume that, for a specific year $t$, firms in the same industry have the following production function (value added case):

$$
v a_{t}=\beta_{0}+\beta_{l} l_{t}+\beta_{k} k_{t}+w_{t}+\eta_{t}
$$


where $v a_{t}, l_{t}, k_{t}$, and $w_{t}$ are firm's value added, labor input, capital input, and productivity, respectively. All variables are in logarithm. $\eta_{t}$ is an error term and it is assumed to be uncorrelated with all input choices. Firms will make input decision based on their productivity; thus, productivity component is correlated to input choices. Data for $w_{t}$ usually is not available; consequently, conventional method like OLS will lead to bias estimation, unless a proxy for productivity could be included in the regression as control variable.

To construct a proxy for unobserved productivity, Levinsohn and Petrin (2003) make the following assumptions: 1) Demand for the intermediate input, $m_{t}$, is assumed to be depending on the firm's state variable $k_{t}$ and $w_{t}$. More specifically, Levinsohn and Petrin (2003) illustrate that demand $m_{t}$ is a monotonous (increasing) function of $w_{t}$, i.e., $m_{t}=m_{t}\left(k_{t}, w_{t}\right)$. Taking inversion of this intermediate demand function, we have $\left.w_{t}=w_{t}\left(k_{t}, m_{t}\right) .2\right)$ Capital input, $k_{t}$, is a state variable. Labor input, $l_{t}$, is so-called freely variable input that firms are able to adjust when they observe current productivity shock. 3) Productivity, $w_{t}$, follows a first-order Markov process, i.e., $w_{t}=E\left[w_{t} \mid w_{t-1}\right]+\xi_{t}$, where $\xi_{t}$ is an innovation to productivity that is uncorrelated with $k_{t}$, but is allowed to be correlated with $l_{t}$. In this paper, we follow the default LP algorithm and assume that $l_{t}$ is uncorrelated with $\xi_{t}$. Given these assumptions, we have

$$
\begin{aligned}
v a_{t} & =\beta_{0}+\beta_{l} l_{t}+\beta_{k} k_{t}+w_{t}+\eta_{t} \\
& =\beta_{l} l_{t}+\phi_{t}\left(k_{t}, m_{t}\right)+\eta_{t}
\end{aligned}
$$

where

$$
\phi_{t}\left(k_{t}, m_{t}\right)=\beta_{0}+\beta_{k} k_{t}+w_{t}\left(k_{t}, m_{t}\right)
$$

The first step of Levinsohn and Petrin (2003) algorithm is to estimate the above regression function by OLS and a third-order polynomial approximation in $k_{t}$ and $w_{t}$ is used as a proxy for unobserved productivity component, i.e., the first step regression function is

$$
v a_{t}=\delta_{0}+\beta_{l} l_{t}+\sum_{i=0}^{3} \sum_{j=0}^{3-i} \delta_{i j} k_{t}^{i} m_{t}^{j}+\eta_{t}
$$

A consistent estimate of $\beta_{l}, \hat{\beta}_{l}$, is obtained after this step, given that $l_{t}$ and $\xi_{t}$ are not correlated. We then have $\hat{\phi}_{t}=\widehat{v a}_{t}-\hat{\beta}_{l} l_{t}$ and $\hat{w}_{t}=\hat{\phi}_{t}-\hat{\beta}_{k} k_{t}$. At this stage, it is suggested that $\hat{\beta}_{k}$ could take any 
reasonable initial value, denoted as $\beta_{k}^{*}$ (Petrin et al., 2004), i.e., $\hat{w}_{t}=\hat{\phi}_{t}-\beta_{k}^{*} k_{t} \cdot{ }^{11}$ Given these estimates, a consistent (nonparametric) approximation of $E\left[w_{t} \mid w_{t-1}\right]$, denoted as $E\left[\widehat{w_{t} \mid w_{t-1}}\right]$ could be obtained by using the predicted values from the following regression:

$$
w_{t}=\gamma_{0}+\gamma_{1} w_{t-1}+\gamma_{2}\left(w_{t-1}\right)^{2}+\gamma_{1}\left(w_{t-3}\right)^{3}+\varepsilon_{t}
$$

where both dependent and independent variables come from $\hat{w}_{t}=\hat{\phi}_{t}-\beta_{k}^{*} k_{t}$. Consequently, we have $\widehat{\eta_{t}+\xi_{t}}=v a_{t}-\hat{\beta}_{l} l_{t}-\beta_{k}^{*} k_{t}-E\left[\widehat{w_{t} \mid w_{t-1}}\right]$.

The second and the final step is to use appropriate instruments to obtain consistent estimates for $\hat{\beta}_{k}$ based on $\widehat{\eta_{t}+\xi_{t}}=v a_{t}-\hat{\beta}_{l} l_{t}-\beta_{k}^{*} k_{t}-E\left[\widehat{w_{t} \mid w_{t-1}}\right]$. It is assume that capital stock in the current period, $k_{t}$, is determined by the previous investment decisions. Consequently, current capital stock does not respond to shocks to this period's productivity innovation term $\xi_{t}$, which leads to the first moment condition $E\left[\eta_{t}+\xi_{t} \mid k_{t}\right]=0$. Note also that the previous period's level of material input, $m_{t-1}$, is uncorrelated with current period's error term, i.e., $E\left[\eta_{t}+\xi_{t} \mid m_{t-1}\right]=0$. Other possible moment conditions include $E\left[\eta_{t}+\xi_{t} \mid l_{t-1}\right]=0, E\left[\eta_{t}+\xi_{t} \mid k_{t-1}\right]=0$, and $E\left[\eta_{t}+\xi_{t} \mid m_{t-2}\right]=0$.

\footnotetext{
${ }^{11}$ We employ Stata command 'levpet' for production function estimation and TFP calculation. A two-dimensional grid search with candidate values for $\beta_{k}^{*}$ range from 0.01 to 0.99 , in increments of 0.01 are used in the algorithm.
} 
TABLE 1

Empirical Results

\begin{tabular}{|c|c|c|c|c|c|c|}
\hline & \multicolumn{3}{|c|}{ TFP Measure 1} & \multicolumn{3}{|c|}{ TFP Measure 2} \\
\hline & $\begin{array}{c}\text { Truncated } \\
\text { Matrix } W^{c 1}\end{array}$ & $\begin{array}{c}\text { Truncated } \\
\text { Matrix } W^{c 2}\end{array}$ & $\begin{array}{l}\text { No truncation } \\
\text { in } W\end{array}$ & $\begin{array}{c}\text { Truncated } \\
\text { Matrix } W^{c 1}\end{array}$ & $\begin{array}{c}\text { Truncated } \\
\text { Matrix } W^{c 2}\end{array}$ & $\begin{array}{l}\text { No truncation } \\
\text { in } W\end{array}$ \\
\hline First order time lagged TFP & $\begin{array}{c}0.154 * * \\
(0.076)\end{array}$ & $\begin{array}{c}0.192 * * * \\
(0.044)\end{array}$ & $\begin{array}{c}0.160 * * * \\
(0.055)\end{array}$ & $\begin{array}{c}0.790 * * * \\
(0.057)\end{array}$ & $\begin{array}{c}0.750 * * * \\
(0.057)\end{array}$ & $\begin{array}{c}0.778 * * * \\
(0.082)\end{array}$ \\
\hline SOE presence: fixed asset share & $\begin{array}{c}-6.761 * * * \\
(1.223)\end{array}$ & $\begin{array}{c}-4.762 * * * \\
(1.077)\end{array}$ & $\begin{array}{c}-6.091 * * * \\
(0.782)\end{array}$ & $\begin{array}{c}0.664 \\
(0.736)\end{array}$ & $\begin{array}{c}-0.728 * * \\
(0.302)\end{array}$ & $\begin{array}{c}-0.741 * * * \\
(0.206)\end{array}$ \\
\hline FDI presence: sales income share & $\begin{array}{c}-9.343 * * * \\
(0.897)\end{array}$ & $\begin{array}{c}-8.350 * * * \\
(1.064)\end{array}$ & $\begin{array}{c}-9.010^{* * * *} \\
(0.851)\end{array}$ & $\begin{array}{c}-1.340 * * * \\
(0.505)\end{array}$ & $\begin{array}{l}-0.477 \\
(0.422)\end{array}$ & $\begin{array}{l}-0.041 \\
(0.297)\end{array}$ \\
\hline Spatially lagged TFP & $\begin{array}{c}0.147 * * \\
(0.061)\end{array}$ & $\begin{array}{l}0.191^{*} \\
(0.099)\end{array}$ & $\begin{array}{c}0.256 * * * \\
(0.046)\end{array}$ & $\begin{array}{c}0.454 * * * \\
(0.122)\end{array}$ & $\begin{array}{c}0.632 * * \\
(0.273)\end{array}$ & $\begin{array}{c}0.521 * * \\
(0.216)\end{array}$ \\
\hline Spatially lagged SOE presence: fixed asset share & $\begin{array}{c}3.239 * * * \\
(0.754)\end{array}$ & $\begin{array}{c}3.550 * * * \\
(1.331)\end{array}$ & $\begin{array}{l}-1.205 \\
(1.440)\end{array}$ & $\begin{array}{c}2.370 * * * \\
(0.651)\end{array}$ & $\begin{array}{l}4.841 * * \\
(2.110)\end{array}$ & $\begin{array}{c}1.074 \\
(1.287)\end{array}$ \\
\hline Spatially lagged FDI presence: sales income share & $\begin{array}{c}-6.362 * * \\
(2.864)\end{array}$ & $\begin{array}{c}-7.133 * * \\
(3.174)\end{array}$ & $\begin{array}{c}-13.093 * * * \\
(3.990)\end{array}$ & $\begin{array}{c}-1.493 * * \\
(0.583)\end{array}$ & $\begin{array}{c}-2.463 * * \\
(1.053)\end{array}$ & $\begin{array}{l}-4.834^{*} \\
(2.611)\end{array}$ \\
\hline Hansen Statistic & 10.255 & 17.241 & 30.726 & 8.404 & 6.035 & 9.237 \\
\hline Hansen Statistic $p$-value & 0.923 & 0.244 & 0.629 & 0.816 & 0.812 & 0.600 \\
\hline D.O.F of Hansen Statistic & 18 & 14 & 34 & 13 & 10 & 11 \\
\hline Number of Instruments & 33 & 29 & 49 & 28 & 25 & 26 \\
\hline $\mathrm{N}$ & 8642 & 8642 & 8642 & 7513 & 7513 & 7513 \\
\hline
\end{tabular}

Notes:

(a) $* p<0.10,{ }^{* *} p<0.05,{ }^{* * *} p<0.01$. (b) Results reported are all two-step System-GMM estimates with Windmeijer (2005) correction for standard errors. (c) Collapsed instrument matrix technique is employed to reduce instrument count. (d) Hansen test statistics reported are two-step versions. (e) Truncated matrix $W^{c 1}$ keeps the closest $1 / 5$ neighbors and weights for other neighbors are truncated to zero entries. Truncated matrix $W^{c 2}$ keeps the closest $3 / 5$ neighbors. (f) Both TFP measure 1 and 2 are constructed by firstly estimate firm-level TFP using Levinsohn and Petrin (2003) algorithm and then aggregate to county level using weighted average with the weight being the value added share of the firm in the underlying county. (g) The difference between TFP measure 1 and 2 are mainly due to using different capital input and deflators in the process of firm-level TFP estimation. For TFP measure 1 we use the sum of average circulating capital and net value of fixed assets as proxy for capital input, which is deflated by investment deflators obtained from various issues of Chinese Statistics Yearbook. For TFP measure 2, both capital input and deflator follow Brandt, Van Biesebroeck, and Zhang (2012 and 2014). Firms with missing or negative net capital stock at original purchase prices or with number of employee less than 8 are dropped before the estimation of TFP measure 2. This results in a smaller sample size. See Appendix A for further explanation. 
TABLE 2

Empirical Results

\begin{tabular}{|c|c|c|c|c|c|c|}
\hline & \multicolumn{3}{|c|}{ TFP Measure 1} & \multicolumn{3}{|c|}{ TFP Measure 2} \\
\hline & $\begin{array}{c}\text { Truncated } \\
\text { Matrix } W^{c 1}\end{array}$ & $\begin{array}{c}\text { Truncated } \\
\text { Matrix } W^{c 2}\end{array}$ & $\begin{array}{l}\text { No truncation } \\
\text { in } W\end{array}$ & $\begin{array}{c}\text { Truncated } \\
\text { Matrix } W^{c 1}\end{array}$ & $\begin{array}{c}\text { Truncated } \\
\text { Matrix } W^{c 2}\end{array}$ & $\begin{array}{l}\text { No truncation } \\
\text { in } W\end{array}$ \\
\hline First order time lagged TFP & $\begin{array}{c}0.186^{* *} \\
(0.080)\end{array}$ & $\begin{array}{c}0.201 * * * \\
(0.042)\end{array}$ & $\begin{array}{c}0.143 * * \\
(0.063)\end{array}$ & $\begin{array}{c}0.772 * * * \\
(0.137)\end{array}$ & $\begin{array}{c}0.859 * * * \\
(0.113)\end{array}$ & $\begin{array}{c}0.532 * * * \\
(0.040)\end{array}$ \\
\hline SOE presence: fixed asset share & $\begin{array}{c}-6.108 * * * \\
(1.345)\end{array}$ & $\begin{array}{c}-4.335 * * * \\
(0.779)\end{array}$ & $\begin{array}{c}-6.717 * * * \\
(0.978)\end{array}$ & $\begin{array}{c}-3.379 * * * \\
(1.252)\end{array}$ & $\begin{array}{c}-0.678^{* *} \\
(0.269)\end{array}$ & $\begin{array}{c}-0.783 * * * \\
(0.186)\end{array}$ \\
\hline FDI presence: employment share & $\begin{array}{c}-8.894 * * * \\
(0.782)\end{array}$ & $\begin{array}{c}-7.163 * * * \\
(0.574)\end{array}$ & $\begin{array}{c}-9.191 * * * \\
(0.944)\end{array}$ & $\begin{array}{c}-1.703 * * * \\
(0.447)\end{array}$ & $\begin{array}{c}0.615 \\
(0.436)\end{array}$ & $\begin{array}{l}-0.635^{*} \\
(0.367)\end{array}$ \\
\hline Spatially lagged TFP & $\begin{array}{c}0.132 * * \\
(0.061)\end{array}$ & $\begin{array}{c}0.074 * * \\
(0.037)\end{array}$ & $\begin{array}{c}0.146^{* *} \\
(0.060)\end{array}$ & $\begin{array}{c}0.573 * * \\
(0.233)\end{array}$ & $\begin{array}{c}0.506^{* * *} \\
(0.178)\end{array}$ & $\begin{array}{c}0.662 * * * \\
(0.145)\end{array}$ \\
\hline Spatially lagged SOE presence: fixed asset share & $\begin{array}{c}1.896^{* * * *} \\
(0.268)\end{array}$ & $\begin{array}{r}2.913 * * \\
(1.395)\end{array}$ & $\begin{array}{l}-4.185 \\
(2.566)\end{array}$ & $\begin{array}{l}-0.052 \\
(0.529)\end{array}$ & $\begin{array}{l}2.554^{*} \\
(1.415)\end{array}$ & $\begin{array}{l}-2.134 \\
(1.303)\end{array}$ \\
\hline Spatially lagged FDI presence: employment share & $\begin{array}{c}-4.695 * * \\
(2.105)\end{array}$ & $\begin{array}{l}-3.072 \\
(2.566)\end{array}$ & $\begin{array}{c}1.437 \\
(4.422)\end{array}$ & $\begin{array}{l}-2.488^{*} \\
(1.340)\end{array}$ & $\begin{array}{c}-1.556 * * * \\
(0.578)\end{array}$ & $\begin{array}{c}0.276 \\
(1.424)\end{array}$ \\
\hline Hansen Statistic & 13.117 & 27.495 & 19.492 & 5.211 & 10.944 & 30.365 \\
\hline Hansen Statistic $p$-value & 0.664 & 0.597 & 0.490 & 0.995 & 0.859 & 0.599 \\
\hline D.O.F of Hansen Statistic & 16 & 30 & 20 & 16 & 17 & 33 \\
\hline Number of Instruments & 31 & 45 & 35 & 31 & 32 & 48 \\
\hline $\mathrm{N}$ & 8642 & 8642 & 8642 & 7513 & 7513 & 7513 \\
\hline
\end{tabular}

Notes:

(a) $* p<0.10, * * p<0.05, * * * p<0.01$. (b) Results reported are all two-step System-GMM estimates with Windmeijer (2005) correction for standard errors. (c) Collapsed instrument matrix technique is employed to reduce instrument count. (d) Hansen test statistics reported are two-step versions. (e) Truncated matrix $W^{c 1}$ keeps the closest $1 / 5$ neighbors and weights for other neighbors are truncated to zero entries. Truncated matrix $W^{c 2}$ keeps the closest $3 / 5$ neighbors. (f) Both TFP measure 1 and 2 are constructed by firstly estimate firm-level TFP using Levinsohn and Petrin (2003) algorithm and then aggregate to county level using weighted average with the weight being the value added share of the firm in the underlying county. (g) The difference between TFP measure 1 and 2 are mainly due to using different capital input and deflators in the process of firm-level TFP estimation. For TFP measure 1 we use the sum of average circulating capital and net value of fixed assets as proxy for capital input, which is deflated by investment deflators obtained from various issues of Chinese Statistics Yearbook. For TFP measure 2, both capital input and deflator follow Brandt, Van Biesebroeck, and Zhang (2012 and 2014). Firms with missing or negative net capital stock at original purchase prices or with number of employee less than 8 are dropped before the estimation of TFP measure 2. This results in a smaller sample size. See Appendix A for further explanation. 
FIGURE 1

FDI Spatial Density Distribution at County Level in 2007

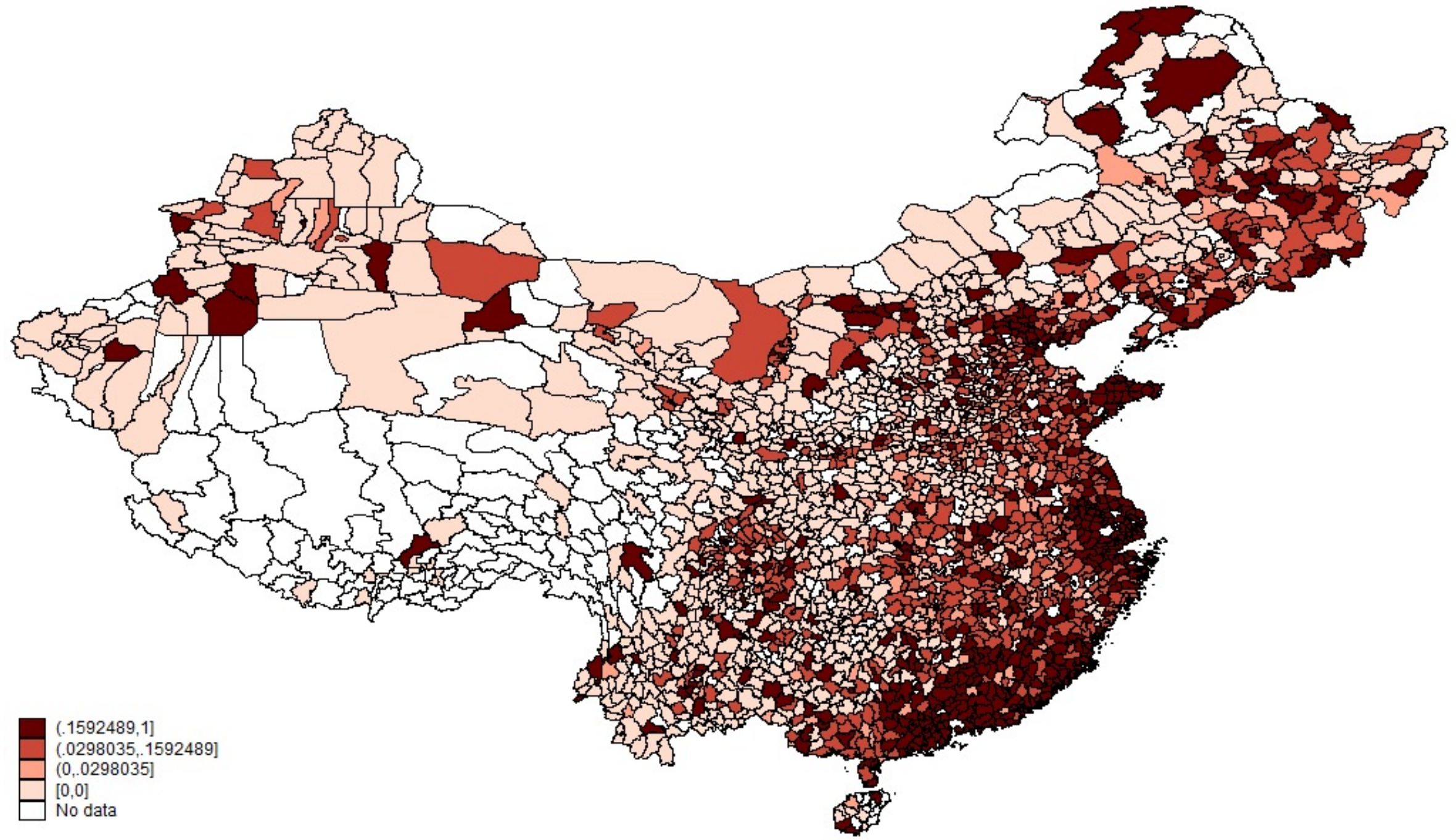

Source: Authors' calculation based on NBS-CIE database. FDI density is measured by fixed asset share of FDI in each county, i.e., the value of fixed asset of foreign firms divided by the total fixed asset in a county. The color code on the map indicates the classes of density, with the darkest color corresponding to the class of the highest density. 
FIGURE 2

TFP Spatial Distribution of Chinese Domestic Private Firms in 2007

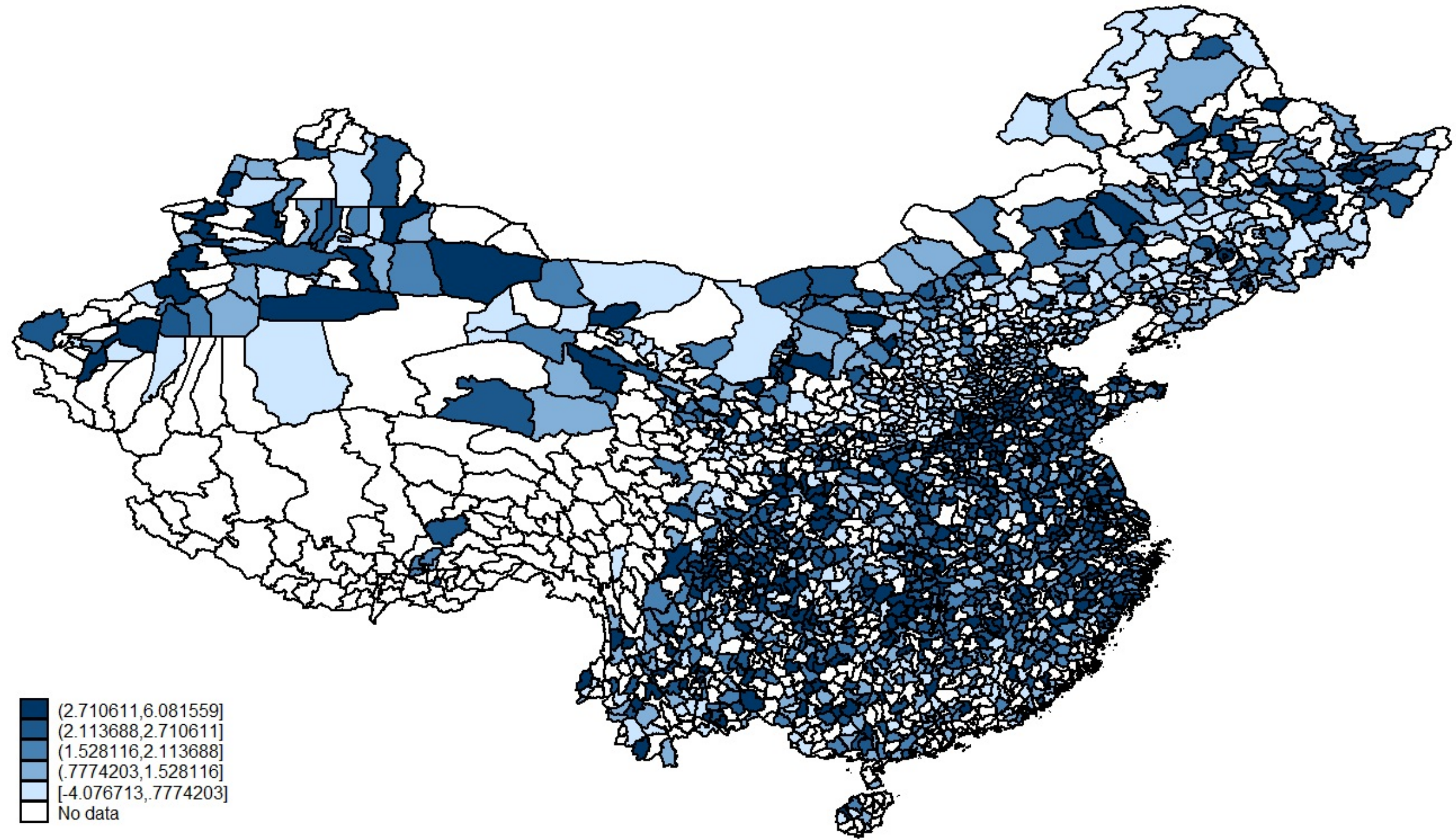

Source: Authors' calculation based on NBS-CIE database. County level TFPs are constructed as the weighted average of firm-level $\ln ($ TFP)s with the weights being the value added shares of the firm in the underlying county. The color code on the map indicates the level of TFP, with the darkest color corresponding to the class of the highest TFP. 


\section{References}

Abraham, F., Konings, J., and Slootmaekers, V. (2010) 'FDI spillovers in the Chinese manufacturing sector', Economics of Transition, 18, 143-182.

Aitken, B.J. and Harrison, A.E. (1999), 'Do domestic firms benefit from direct foreign investment? Evidence from Venezuela', American Economic Review, 89, 605-618.

Anselin, L. (2001), 'Spatial econometrics', In: Baltagi, B., ed., A Companion to Theoretical Econometrics (Cambridge, MA: Blackwell Publisher), Chapter 14, 310-330.

Arellano, M. and Bond, S. (1991), 'Some tests of specification for panel data: Monte-Carlo evidence and an application to employment equations', Review of Economic Studies, 58, 277297.

Arellano, M. and Bover, O. (1995), 'Another look at the instrumental variable estimation of errorcomponents models', Journal of Econometrics, 68, 29-51.

Audretsch, D. B. and Feldman, M. (1996), 'Spillovers and the geography of innovation and production', American Economic Review, 86, 630-640.

Bai, C.E., Li, D., Tao, Z.G., and Wang, Y.J. (2000) 'A Multitask Theory of State Enterprise Reform', Journal of Comparative Economics, Elsevier, vol. 28(4), pages 716-738, December.

Bai, C.E., Du, Y.J., Tao, Z.G., and Tong, S.Y. (2004) 'Local protectionism and regional specialization: evidence from China's industries', Journal of International Economics, Elsevier, vol. 63(2), pages 397-417, July.

Balsvik, R. (2011) 'Is Labor Mobility a Channel for Spillovers from Multinationals? Evidence from Norwegian Manufacturing', Review of Economics and Statistics, February 2011, Vol. 93, No. 1, Pages 285-297.

Blomström, M. and Kokko, A. (1998) 'Multinational Corporations and Spillovers', Journal of Economic Surveys, Vol. 12, No. 3, pp 247-277.

Blonigen, B.A., Ellis, C.J. and Fausten, D. (2005), 'Industrial groupings and foreign direct investment', Journal of International Economics, 65, 75-91.

Blundell, R. and Bonds, S. (1998), 'Initial conditions and moment restrictions in dynamic panel data models', Journal of Econometrics, 87, 115-143.

Boschma, R.A. and Frenken, K. (2010), 'The spatial evolution of innovation networks. A proximity perspective', in R. A. Boschma, R. Martin (eds), The Handbook of Evolutionary Economic Geography (Cheltenham: Edward Elgar), 120-135. 
Broekel, T. and Boschma, R. (2012) 'Knowledge networks in the Dutch aviation industry: the proximity paradox', Journal of Economic Geography, 12, 409-433.

Brandt, L., Van Biesebroeck, J., and Zhang, Y.F. (2012) 'Creative Accounting or Creative Destruction? Firm-level Productivity Growth in Chinese Manufacturing', Journal of Development Economics, 97, 339-351.

Brandt, L., Van Biesebroeck, J., and Zhang, Y.F. (2014) 'Challenges of Working with the Chinese NBS Firm-Level Data', China Economic Review, 30, 339-352.

Cassi, L. and Plunket, A. (2013) 'Proximity, network formation and innovative performance: in search of the proximity paradox', MPRA Paper No. 47388.

Cheng, L.K. and Kwan, Y.K. (2000a), 'What are the determinants of the location of foreign direct investment? The Chinese experience', Journal of International Economics, 51, 379-400.

Cheng, L.K. and Kwan, Y.K. (2000b), 'The location of foreign direct investment in Chinese regions: further analysis of labor quality'. In: Ito T. and Krueger A.O. (Eds.), The Role of Foreign Direct Investment in East Asian Economic Development (Chicago, IL: University of Chicago Press), 213-235.

Crespo, N., Fontoura, M.P., and Proença, I. (2009) 'FDI spillovers at regional level: Evidence from Portugal', Papers in Regional Science, 88, 591-607.

Gertler, M.S. (2003), 'Tacit knowledge and the economic geography of context or the undefinable tacitness of being there', Journal of Economic Geography, 3, 75-99.

Glass A. and Saggi, K. (1998) 'International technology transfer and the technology gap', Journal of Development Economics, 55, 369-398.

Görg, H. and Greenaway, D. (2004), 'Much ado about nothing? Do domestic firms really benefit from foreign direct investment', World Bank Research Observer, 19, 171-197.

Görg, H. and Strobl, E. (2005), 'Foreign direct investment and local economic development: Beyond productivity spillovers', In: Moran, T., Graham, E. and Blomstrom, M., ed., Does Foreign Direct Investment Promote Economic Development (Washington, DC: Peterson Institute for International Economics), Chapter 6, 137-157.

Head, K., Ries, J. and Swenson, D. (1995), 'Agglomeration Benefits and Location Choice: Evidence from Japanese Manufacturing Investments in the United-States', Journal of International Economics, 38, 223-247.

Hale, G. and Long, C. (2011) 'Are there productivity spillovers from foreign direct investment in China?’ Pacific Economic Review, 16, 135-153. 
Huang, Y.S. (1998) Selling China: Foreign Investment during the Reform Era, Cambridge University Press.

Huang, Y.S. (2008) Capitalism with Chinese Characteristics, Cambridge University Press.

Huang, Y.S., Ma, Y, Yang, Z. and Zhang, Y.F, (2008) 'A Fire Sale without Fire: An Explanation of Labor-Intensive FDI in China’, MIT Sloan Research Paper No. 4713-08.

Jacobs, J.P.A.M., Jenny, E.L. and Hendrik, V. (2009), Dynamic panel data models featuring endogenous interaction and spatially correlated errors. Discussion Paper Tilburg University, Center for Economic Research.

Javorcik, B.S., (2004) 'Does foreign direct investment increase the productivity of domestic firms? In search of spillovers through backward linkages', American Economic Review, 94, 605-627.

Kokko, A. (1994), 'Technology, Market Characteristics, and Spillovers', Journal of Development Economics, 43, 279-293.

Kokko, A. (1996) 'Productivity Spillovers from Competition between Local Firms and Foreign Affiliates', Journal of International Development, Vol. 8, pp 517-530.

Kukenova, M. and Monteiro, J.A. (2009), 'Spatial dynamic panel model and system GMM: a Monte Carlo investigation', MPRA working paper, No.14319.

Levinsohn, J. and Petrin, A. (2003), 'Estimating production functions using inputs to control for unobservables'. Review of Economic Studies 70, 317-341.

Lin, M. and Kwan, Y.K. (2011), 'Sectional location of FDI in China', The World Economy, 34, 1181-1198.

Lin, P., Liu, Z. and Zhang, Y. (2009), 'Do Chinese domestic firms benefit from FDI inflow? Evidence of horizontal and vertical spillovers', China Economic Review, 20, 677-691.

Liu, Z.Q. (2002), 'Foreign direct investment and technology spillover: Evidence from China', Journal of Comparative Economics, 30, 579-602.

Madariaga, N. and Poncet, S. (2007), 'FDI in Chinese cities: Spillovers and impact on growth', The World Economy, 30, 837-862.

Markusen, J. R. and Trofimenko, N. (2009) 'Teaching locals new tricks: Foreign experts as a channel of knowledge transfers,' Journal of Development Economics, Elsevier, vol. 88(1), pages 120-131. 
Ouyang, P. and Fu, S.H. (2012), 'Economic growth, local industrial development and inter-regional spillovers from foreign direct investment: Evidence from China', China Economic Review, Volume 23, Issue 2, June 2012, Pages 445-460.

Petrin, A., Brian P., and Levinsohn, J. (2004), 'Production function estimation in Stata using inputs to control for unobservables'. The Stata Journal, 4(2), 113-123.

Perkins D.H., Rawski T.G. (2008), 'Forecasting China's Economic Growth to 2025', in Brandt, L. and Rawski, T.G. (eds.), China's Great Economic Transformation, Cambridge University Press, 829-886.

Rey, S.J. and Montouri, B.D. (1999), 'US regional income convergence: a spatial econometric perspective', Regional Studies, 33, 143-156.

Tanaka, K. and Hashiguchi, Y. (2012), 'Spatial spillovers from FDI agglomeration: evidence from the Yangtze River Delta in China', IDE discussion paper No. 354.

Windmeijer, F. (2005), 'A finite sample correction for the variance of linear efficient two-step GMM estimators', Journal of Econometrics, 126, 25-51.

$\mathrm{Xu}, \mathrm{X}$. and Sheng, Y. (2012), 'Productivity spillovers from foreign direct investment: Firm level evidence from China', World Development, 40, 62-74. 